\title{
A Case of Chronic Noninvasive Actinomycosis in the Nasal Cavity
}

\author{
Jae Ho Lee ${ }^{1}$, Ji Yun Jeong ${ }^{2}$, Jung Soo Kim¹, and Sung Jae Heo ${ }^{1}$ \\ ${ }^{1}$ Departments of Otorhinolaryngology-Head and Neck Surgery, ${ }^{2}$ Pathology, School of Medicine, Kyungpook National University, \\ Daegu, Korea
}

\section{만성 비침습성 비강 방선균증 1 예}

이재호 ${ }^{1} \cdot$ 정지윤 $^{2} \cdot$ 김정수 $^{1} \cdot$ 허성재 $^{1}$

경북대학교 의학전문대학원 이비인후-두경부외과학교실, ${ }^{1}$ 병리학교실 ${ }^{2}$

\author{
Received September 18, 2016 \\ Revised October 19, 2016 \\ Accepted October 24, 2016 \\ Address for correspondence \\ Sung Jae Heo, MD \\ Department of Otorhinolaryngology- \\ Head and Neck Surgery, \\ Kyungpook National University \\ Medical Center, \\ 807 Hoguk-ro, Buk-gu, \\ Daegu 41404, Korea \\ Tel $+82-53-200-5777$ \\ Fax $+82-53-200-2027$ \\ E-mail blueskyhsj@hanmail.net
}

Actinomycosis is a rare anaerobic, gram-positive bacterial infection caused by Actinomyces, which is a normal flora in the gastrointestinal and female genitourinary tracts. The cervicofacial area is a common infection site for actinomycosis, while nasal cavity is rare. Generally, standard treatment of the disease is a long term antibiotics therapy. However, a treatment strategy for nasal actinomycosis has not been established due to its rarity. We present a case of nasal actinomycosis that was managed by surgical removal. A 49-year-old woman visited our clinic with epistaxis and foul odor and nasoendoscopy showed a mass in patient's right nasal cavity. The mass comprised of Actinomyces was easily removed by endoscopic surgery. Further histopathologic examination revealed that the surrounding tissues did not contain Actinomyces, so we stopped applying antibiotics to the patients. No recurrence has been observed for 26 months. We report this rare case of nasal actinomycosis with a literature review regarding treatment. Korean J Otorhinolaryngol-Head Neck Surg 2017;60(3):144-7

Key Words Actinomycosis · Antibiotics · Nasal cavity · Transnasal endoscopic surgery.

\section{서 론}

방선균증(Actinomycosis)은 그람양성, 혐기성, 아포 비형 성, 항산성 세균인 방선균(Actinomyces)에 의해 발생하는 드 문 질환이다.1) 방선균은 구강, 위장관, 여성 비뇨생식기 등에 정상균주로 존재하며, 감염력이 약하기 때문에 점막이 손상 되거나 동시감염균이 존재할 때 감염을 일으킨다. ${ }^{1.2)}$ 보통 만 성 화농성 육아종성 감염을 일으켜 종괴나 농양을 형성함으 로써 증상을 유발한다. ${ }^{3)}$ 가장 흔한 침범 부위는 경부 및 얼 굴 부위며, 비강은 매우 드문 발생 부위로 저자들이 알기로 는 지금까지 국내외 총 7예만 보고되었다. ${ }^{24-9)}$ 방선균증의 치 료는 1950년대에 처음 기술된 이후로 지금까지 큰 변화 없이 penicillin의 약물치료가 표준치료로 사용되고 있고, 일반적으 로 4 6주간 정맥주사를 포함한 6 12개월의 항생제 치료가
권해지고 있다. ${ }^{1,10)}$

비강은 공기의 통로이기 때문에 혐기성 균인 방선균이 병 을 일으키기 쉽지 않은 위치로, 혐기 환경인 경부 및 얼굴 부 위와는 분명 다른 환경이다. 하지만, 비강 방선균증은 증례가 매우 드물기 때문에 그에 맞는 치료법은 정립되어 있지 않고, 경부 및 얼굴 부위의 치료와 같은 방법으로 치료되고 있다. 저자들은 비강 앞쪽에 발생한 방선균증 1 예를 경험하였기에 치료 방법에 대한 문헌고찰과 함께 보고하는 바이다.

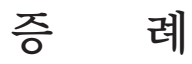

49세 여자 환자가 6개월 전부터 시작된 우측 비강의 코피와 악취를 주소로 내원하였다. 기저질환으로 당뇨를 진단 받았 으나 혈당 조절이 비교적 잘되어 약물복용은 하고 있지 않았 
다. 최근 치과 수술을 했거나 외상을 입은 병력은 없었다. 외 래에서 시행한 비내시경상 우측 비강 앞쪽에 주변 조직과 비 슷한 색의 종괴가 관찰되었다. 이어서 시행한 전산화단층촬 영검사에서 우측 외비공에서 $2 \mathrm{~cm}$ 후방에 석회화로 보이는 고음영이 부분적으로 있는 $1.5 \times 1.5 \mathrm{~cm}$ 의 종괴가 관찰되었 고, 종괴 주변의 골은 녹아서 일부 파괴된 소견이 관찰되었 다(Fig. 1). 코 주위 피부의 종창이나 발적, 통증, 압통 등의 소견은 없었다.

종괴의 일부를 제거하여 병리조직검사를 시행하였고, 그 결
과 유황과립(sulfur granule)이 관찰되었고 가장자리에 실모 양의 균사들이 보이며 그 주위에 주로 중성구로 이루어진 염 증세포들이 둘러싸고 있어 방선균으로 진단되었다(Fig. 2). 종괴를 제거하기 위해 내시경 수술을 시행하였고, 종괴의 외 부에는 선홍색의 육아조직과 같은 연조직이 있었고(Fig. 3A), 외부의 연조직을 제거하니 내부에는 쉽게 부서지는 어두운 갈 색의 진균구와 비슷한 물질이 관찰되었다(Fig. 3B). 종괴는 주 변 조직과 유착 없이 아주 쉽게 분리되어 제거되었고, 주변 점 막에서 부종과 미란은 관찰되었으나 괴사와 같은 심한 염증

Fig. 1. Computed tomography scans. Calcific density (white arrow) and neighboring bone destruction (black arrow) are seen at the anterior nasal cavity in the axial view $(A)$ and coronal view (B)
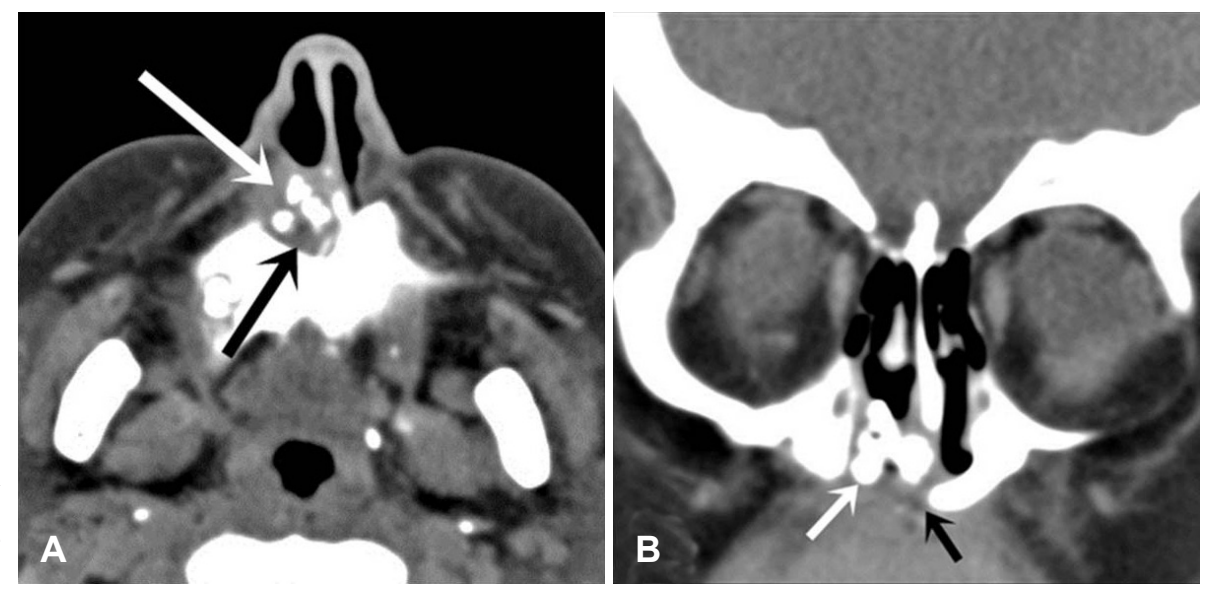

Fig. 2. Histopathologic findings. Hematoxyline and eosin stain $(\times 200)$ shows the sulfur granules and branching filaments surrounded by inflammatory cells (mainly neutrophils) (A). Grocott's methenamine silver stain $(\times 200)$ shows more prominently the sulfur granule and filaments (B).
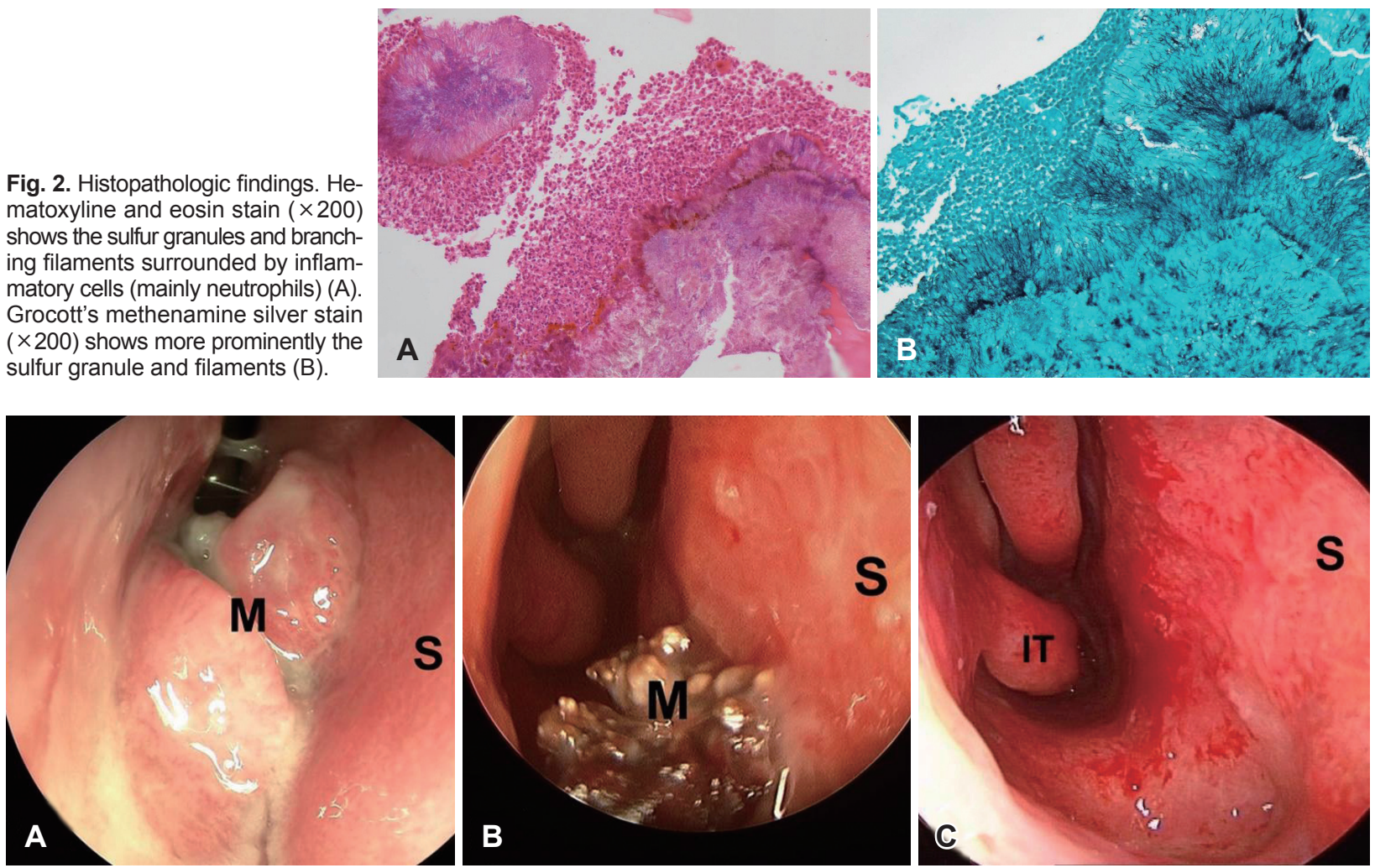

Fig. 3. Nasoendoscopy findings. Cherry-red colored mass $(M)$ is located at the anterior area of right nasal cavity $(A)$. After removal of the outer portion of the mass, fragile, dark brown colored materials are observed (B). Neighboring mucosa shows mild edema and erosion (C). S: septum, IT: inferior turbinate. 
소견은 관찰되지 않았다(Fig. 3 C). 주변 점막으로 균의 침범 여부을 확인하기 위해 병변 주위의 점막을 제거하여 조직검 사를 시행하고 수술을 종료하였다. 환자는 특별한 불편함이 나 합병증 없이 수술 당일 퇴원하였다.

퇴원 후 sultamicillin tosylate hydrate $375 \mathrm{mg}\left(\mathrm{UNASYN}^{\circledR}\right.$ Tablets 375 mg; Pfizer Inc., New York, NY, USA)을 하루 에 세 번 경구로 1 주 동안 복용한 후 내원한 외래에서 확인한 조직검사결과 병변 주위 점막 조직에서는 염증 소견만 있었 고 방선균은 관찰되지 않았다. 이러한 소견을 바탕으로 환자 와 추가적인 치료에 대해 상의한 결과 항생제 복용을 중단하 기로 했으며, 26개월 동안 재발소견 없이 추적관찰 중이다.

\section{고 찰}

방선균증은 발생 위치에 따라서 경부안면형(cervicofacial, 41 55\%), 폐흥부형(pulmonothoracic, 15 34\%), 복부골반형 (abdominopelvic, 13 20\%)으로 나누어진다.) 정상적으로 점 막에 존재하는 방선균이 국소 감염이나 외상, 수술 등에 의해 혐기 환경으로 들어가게 되는 경우 발생할 수 있는데, 구강 위 생 불량, 당뇨, 고혈압, 심폐질환, 장기간의 스테로이드 복용 등이 위험요인으로 작용한다. ${ }^{2}$ 본 증례의 경우 외상이나 수술 병력은 없었고, 3 년 전 당뇨로 진단 받았지만 혈당 조절이 잘 되어 약 복용은 하지 않았고, 내원 당시 시행한 혈액검사상 공 복혈당 $106 \mathrm{mg} / \mathrm{dL}$, 당화혈색소 $6.1 \%$ 였기 때문에 당뇨가 본 환자의 비강 방선균증에 미친 영향은 크지 않았을 것으로 생 각된다.

위치에 따른 분류 외에도 임상증상의 특징에 따라서도 분 류되는데, 진행 속도에 따라서 농양을 주로 형성하는 급성, 섬유화 반응을 주로 일으키는 만성, 그리고 급성과 만성의 중 간 특징을 가지는 아급성으로 나누어진다. ${ }^{8)}$ 또한, 주변 조직으 로 진행에 따라서는 침습성(invasive)와 비침습성(noninvasive) 으로도 분류된다. 일반적으로 위치에 따른 분류법이 주로 사
용되고, 침습성과 비침습성으로 나누는 분류는 흔히 사용되 고 있지 않다. 하지만, 진행 속도나 주변 조직의 침범 정도가 치료 방법 결정, 예후 등에 중요하기 때문에 이러한 분류법이 널리 사용되어야 할 것으로 보인다. 방선균증의 흔한 증상은 점진적인 통증, 종창, 발적과 같은 피부색 변화, 경화(induration), 농양 및 누공 형성인데, ${ }^{8)}$ 본 환자에서는 수개월 동안 지속된 코막힘과 악취 외의 다른 증상은 없었고 주변 조직 침 범이 없었기 때문에, 본 증례는 만성 비침습성 방선균증으로 분류될 수 있다.

방선균증의 진단은 균배양 및 조직학적 검사로 이루어진 다. 균배양은 $37^{\circ} \mathrm{C}$ 의 뇌심장배지 및 혈액배지에서 혐기성 환 경 $\left(5 \% \mathrm{CO}_{2}\right)$ 으로 2 3시간 동안 관찰해야 해서 균을 동정하 기 쉽지 않고, 함께 존재하는 혐기성 균들 때문에 동정균의 신뢰성 또한 높지 않다. ${ }^{9)}$ 따라서, 진단은 주로 임상 검사와 병 리조직학적 소견으로 한다. 조직검사상 유황과립의 존재가 진단적 가치가 크지만, 검체의 약 $1 / 3$ 에서만 관찰된다. ${ }^{4}$ 물론, 노카르디아증(norcardiosis)에서도 유황과립이 관찰되지만, 실모양의 그람양성막대균과 유황과립이 함께 존재하는 것은 방선균의 특징적인 소견이다. 조직검사 외에 비내시경겸사와 전산화단층촬영검사를 시행해서 병변의 위치와 범위, 주변 조직으로의 침범 여부 등을 확인해야 한다. 침습성 방선균증 은 주변 점막의 심한 염증과 괴사, 골미란 및 파괴 등을 일으 킬 수 있으므로 악성 종양, 결핵, 베게너 육아종, 진균 감염 등 과의 감별진단이 필요하다.

치료 방법은 penicillin 계열의 항생제 투여와 수술적으로 제거하는 방법이 있는데, 일반적인 기본 치료법은 항생제 투 여이며 항생제 치료를 실패한 경우 수술로 병변을 제거한 다. ${ }^{4,5)}$ 고용량 penicillin 정맥주사를 약 한 달 동안 투여하고 amoxicillin 경구용 항생제를 수개월에서 1년 동안 투여하는 것이 추천되는데, 투여기간에 대해서는 여러 의견들이 존재한 다. ${ }^{6-8)}$ 또한, 증상 및 소견이 모두 사라진 후 4 6주 동안 추가 적인 항생제 투여가 필요하다는 주장도 있다.,6,7,9) 그에 반해

Table 1. Previously reported cases of nasal actinomycosis

\begin{tabular}{|c|c|c|c|c|c|c|c|}
\hline Reference & Sex/age & $I V A B$ & $\begin{array}{c}\text { Dose of IV AB } \\
\text { (per day) }\end{array}$ & $\begin{array}{l}\text { Duration } \\
\text { of IV } A B\end{array}$ & $P O A B$ & $\begin{array}{l}\text { Dose of } \mathrm{PO} \\
\mathrm{AB} \text { (per day) }\end{array}$ & $\begin{array}{l}\text { Duration } \\
\text { of } P O A B\end{array}$ \\
\hline Choi, et al. ${ }^{2)}$ & $F / 37$ & Ampicillin & $3 \mathrm{~g}$ & $6 d$ & Ampicillin & $500 \mathrm{mg}$ & ND \\
\hline Batzakakis, et al. ${ }^{4}$ & $F / 34$ & Penicillin & ND & $3 d$ & Penicillin & ND & 4 wk \\
\hline Kim, et al. ${ }^{5)}$ & $F / 53$ & ND & ND & ND & Amoxicillin-clavulanate & ND & 4 wk \\
\hline Choi, et al. ${ }^{6}$ & $F / 24$ & Amoxicillin-clavulanate & $3.6 \mathrm{~g}$ & $2 d$ & Amoxicillin-clavulanate & ND & $3 w k$ \\
\hline Hong, et al. ${ }^{7)}$ & $\mathrm{F} / 50$ & Ampicillin-sulbactam & $12 \mathrm{~g}$ & $28 d$ & Amoxicillin & $1500 \mathrm{mg}$ & $7 \mathrm{mo}$ \\
\hline Sakuma, et al. ${ }^{8)}$ & $M / 54$ & Ampicillin-sulbactam & $3 \mathrm{~g}$ & $6 d$ & Amoxicilin & $1500 \mathrm{mg}$ & ND \\
\hline Ozcan, et al. ${ }^{9}$ & $\mathrm{~F} / 75$ & None & None & None & Penicillin & ND & $12 \mathrm{wk}$ \\
\hline Present case & $\mathrm{F} / 49$ & None & None & None & Ampicillin-sulbactam & $1125 \mathrm{mg}$ & 1 wk \\
\hline
\end{tabular}

IV AB: intravenous antibioitics, PO AB: oral antibiotics, ND: no data 
방선균증 병변은 주변이 심하게 섬유화되면서 혈류가 감소되 어 항생제의 투과성이 낮기 때문에 수술적으로 제거해야 한 다는 의견도 있다. ${ }^{9}$ 하지만, 이러한 치료법들은 비강이 아닌 다른 부위의 치료 경험을 바탕으로 소개된 방법들로, 보고된 증례가 매우 적은 비강 방선균증에 대한 치료법은 아직 확립 되지 않았다. 지금까지 보고된 비강 방선균증 증례들에서 항 생제의 종류는 모두 penicillin 계열로 큰 차이가 없었는데, 치 료기간에서 정맥투여는 2 28일, 퇴원 후 경구투여는 3주에 서 7개월로 다양하게 나타났다(Table 1)., ${ }^{2,4)}$ 투여용량 또한 정 맥투여의 경우 하루에 3 12 g, 경구투여는 500 1500 mg으로 다양하게 나타났다. 조절되지 않는 당뇨의 기저질환을 가지고, 처음 내원 당시 비내시경 소견상 정상조직을 찾기 힘든 심한 비점막 괴사소견을 나타낸 급성 침습성 방선균증 1 예를 제외 하고는 모든 예에서 재발 없이 잘 치료되었다. 투여기간을 알 수 있는 5예 중 3예에서 3 4주의 비교적 짧은 기간의 경구항 생제 치료에도 완치되었다.

본 증례는 만성 비침습성 방선균증으로 하비도나 중비도 에서 발생한 다른 증례들에 비해 비강 입구 쪽에서 발생하였 기에, 재발 시 쉽게 발견할 수 있고 혐기성 균인 방선균이 쉽게 자라지 않을 것으로 판단되었다. 따라서, 저자들은 이와 같은 증례에서 장기간 항생제 투여의 필요성에 대해서 의문을 가 졌고 환자와 상의해서 일반적인 비강수술 후에 사용하는 기 간 외에 추가적인 항생제 투여는 하지 않았고, 짧은 기간의 항생제 투여에도 병변은 잘 치료되었다. 방선균증은 급성과 아급성 및 만성, 침습성과 비침습성, 그리고 위치에 따라 분 류해서 그에 따라 치료 방법을 달리해야 할 필요가 있을 것 으로 판단된다. 얼굴과 목의 방선균증뿐만 아니라 부비동 방 선균증에서도 항생제가 주된 치료법으로 사용되었지만, ${ }^{1,3)}$ 비 강 방선균증의 경우 대부분 수술과 항생제의 병합요법으로
치료되었고 좋은 결과를 나타내었다. ${ }^{2,4,6,79)}$ 따라서, 비강 방선 균증에서는 다른 부위와 달리 수술과 항생제의 병합요법이 적절하다고 생각되며, 기저질환이 없고 급성 침습성이 아닌 경우에는 수술적 제거만 충분히 된다면 항생제 투여기간이 길지 않아도 될 것으로 보인다. 하지만, 비강 방선균증의 증례 가 매우 드물어서 더 많은 비강 방선균증의 치료 결과들이 보 고되어야 적절한 치료법이 확립될 수 있을 것으로 생각된다.

\section{REFERENCES}

1) Vorasubin N, Wu AW, Day C, Suh JD. Invasive sinonasal actinomycosis: case report and literature review. Laryngoscope 2013;123(2):334-8.

2) Choi JW, Lee TB, Hwang SH, Kim BH. A rare case of actinomycosis in nasal cavity with aspergillus sinusitis. Korean J Otolaryngol-Head Neck Surg 1997;40(12):1844-7.

3) Moghimi M, Salentijn E, Debets-Ossenkop Y, Karagozoglu KH, Forouzanfar T. Treatment of cervicofacial actinomycosis: a report of 19 cases and review of literature. Med Oral Patol Oral Cir Bucal 2013;18(4):e627-32.

4) Batzakakis D, Karkos PD, Papouliakos S, Leong SC, Bardanis I. Nasal actinomycosis mimicking a foreign body. Ear Nose Throat J 2013;92(7):E14-6.

5) Kim SD, Lee JH, Yun KJ. A case of canaliculitis due to actinomycesinfected nasolacrimal stent in the inferior meatus. Korean J Otorhinolaryngol-Head Neck Surg 2008;51(2):183-5.

6) Choi HJ, Lee JK, Kwon HJ, Lee KC. A case of actinomycosis in nasal cavity. J Rhinol 2007;14(2):128-30.

7) Hong SJ, Joo JB, Kim YJ, Lee BJ. Three cases of actinomycosis of the head and neck. Korean J Otolaryngol-Head Neck Surg 2000; 43(11):1259-62.

8) Sakuma Y, Yamashita Y, Shiono O, Oridate N. Actinomycosis arising from the nasal cavity, with rare fatal progression. BMJ Case Rep 2016;2016:bcr2015213747.

9) Ozcan C, Talas D, Görür K, Aydin O, Yildiz A. Actinomycosis of the middle turbinate: an unusual cause of nasal obstruction. Eur Arch Otorhinolaryngol 2005;262(5):412-5.

10) Fishe AM, Harvey JC. Actinomycosis: some concepts of therapy and prognosis. Postgrad Med 1956;19(1):32-5. 